Milica Jovanović ${ }^{1}$

University of Nis, Faculty of Economics
SCIENTIFIC REVIEW ARTICLE doi:10.5937/ekonomika1801065J

Received: December, 15, 2017

Accepted: February, 26, 2018

\title{
INNOVATION OF SERBIA IN RELATION TO NEIGHBORING COUNTRIES AS A DETERMINANT OF COMPETITIVENESS
}

\begin{abstract}
In a knowledge-based economy, innovation plays a key role in strengthening competitiveness, both on micro and macro-level. Modern countries compete on the basis of technological innovations and allocate significant resources for research and development. The aim of this paper is to point out the key limitations of Serbia's innovation as a determinant of national competitiveness, applying the methodology of the World Economic Forum. The comparative analysis will show which countries in the region are positive examples from the aspect of innovation and in relation to which indicators of innovation Serbia has the worst position, considering a seven-year period. A special emphasis is put on the possibilities of overcoming the weaknesses of Serbia's innovation.
\end{abstract}

Key words: innovations, competitiveness, Global Competitiveness Index, Serbia, neighboring countries

JEL classification: $\mathbf{O 3 0}$

\section{ИНОВАТИВНОСТ СРБИЈЕ У ОДНОСУ НА ЗЕМЉЕ У ОКРУЖЕЊУ КАО ДЕТЕРМИНАНТА КОНКУРЕНТНОСТИ}

\begin{abstract}
Апстракт
У економији заснованој на знању, иновације имају кључну улогу у јачању конкурентности, на микро и на макро нивоу. Савремене земље конкуришу на бази технолошких иноващија и издвајају значајна средства за истраживање и развој. Циљ рада је указати на кључна ограничења иновативности Србије као детерминанте националне конкурентности, примењујући методологију Светског економског форума. Компаративна анализа ће показати које се земље из окружења издвајају као позитивни примери са аспекта иновативности и у односу на које индикаторе иновативности имамо најлотију позииију, посматрајући седмогодишњи период. Посебан нагласак се ставља на могућности за превазилажење слабости домаће иновативности.
\end{abstract}

Кључне речи: иновације, конкурентност, Индекс глобалне конкурентности, Србија, земље у окружењу

\footnotetext{
1 jovanovicmilicaa90@gmail.com 


\section{Introduction}

In the new era, the era of knowledge-based economy, innovations are becoming imperative, and the main goal is to turn ideas into innovations. With the change in the environment in which modern companies operate, traditional sources of growth are losing importance and are being replaced by education, knowledge, innovations and entrepreneurship. As early as the 1930s, Joseph Schumpeter (1934) recognized the importance of innovations, which represent a primary driver of dynamic economic development. Modern developed countries are becoming more competitive in terms of increased resource allocations for research and development and in terms of the development of technological innovations. With the aim of sustaining the achieved competitive advantage, the most developed countries in the world are inventing new technological products and are the leaders in that field. They are characterized by a close cooperation between universities and industry, high quality scientific research institutions, significant resource allocations for research and development given by the private sector, a large number of patents and a strict regulation for the protection of intellectual property, which are the key indicators of innovation of national economy, as well as important factors of competitiveness.

The main problems of the business environment in Serbia are related to the massive brain drain, insufficient investment in research and development by the state and by the private sector as well, slow adoption of new technologies, inadequate cooperation between universities and industry, unavailability of research services, inefficient protection of intellectual property. These are the basic restrictions on domestic innovation, which can seriously jeopardize national competitiveness, especially at higher levels of development. Yet, compared to the neighboring countries, when it comes to innovation, our country has significantly improved its position in the past couple of years. According to the latest results, certain indicators of innovation such as the quality of scientific research institutions and patent application show that Serbia has attained a favorable position, which sets it apart from other neighboring countries, while the innovation capacity is seen as the biggest limitation of domestic innovation.

The aim of this paper is to indicate the fundamental weaknesses and problems of domestic innovation, as important determinants of national competitiveness, using the comparative method. The analysis includes Serbia and other countries in the region: Albania, Bosnia and Herzegovina, Bulgaria, Croatia, Hungary, Macedonia, Montenegro, Romania and Slovenia, over a seven-year period. The goal is to indicate possibilities for the improvement of national competitiveness by stressing the importance of certain indicators that represent the basis of the methodology of the World Economic Forum for the analysis of national competitiveness- The Global Competitiveness Index. By closely observing the indicators that represent the base of the twelfth pillar of competitiveness, we can understand the reasons for Serbia's position improvement in the field of innovations, which are becoming the key factor for achieving competitive advantage in modern economies. 


\section{Innovation as a pillar of the Global Competitiveness Index}

"The World Economic Forum defines competitiveness as the set of institutions, policies, and other factors that determine the level of productivity of a country. The indicator of the level of competitiveness is called the Global Competitiveness Index (GCI) and it deals with determining the average value of several microeconomic and macroeconomic components, which are individually measured on a scale from 1 to 7 . All of the measured indicators are grouped into twelve pillars and reflect different aspects of the complex economic reality" (Despotović, 2016, p. 82). The methodology of the World Economic Forum for the assessment of national competitiveness is based on more than 110 indicators, or factors of competitiveness that are divided into 12 categories, the so-called pillars of competitiveness, and the analysis includes around 140 countries in the world. The data obtained are based on the attitudes of the leading managers (primary data) in the analyzed countries, or on the reports of other international organizations such as the World Bank, the IMF, the International Trade Organization, United Nations (solid data).The importance of individual groups of pillars of competitiveness for a specific country depends on the stage of development of that country. The criterion used for grouping countries according to their stage of development is the realized level of GDP per capita. Countries are divided into three main and two transitional stages of economic development. The stage of development in which a country is determines the value of weights attributed to groups of pillars which form the Global Competitiveness Index ${ }^{2}$ . Moreover, some analyses (Schuller \& Lidbom, 2009) have shown that high-ranking countries in the Global Competitiveness Index Report are ranked high according their GDP per capita, or their standard of living.

Although all of the mentioned pillars are to a certain extent important for all economies, the Global Competitiveness Index stresses the fact that they will affect different economies in different ways. Perez-Moreno, Rodriguez and Luque (2016, p. 399) pointed out that in the first stage of development the economy is factor-driven and countries compete on the basis of unskilled labor force and natural resources. Competitiveness in this stage of development depends on: well-functioning public and private institutions (pillar 1), a well-developed infrastructure (pillar 2), a stable macroeconomic environment (pillar 3) and a healthy workforce that has at least a basic education (pillar 4). When a country becomes more competitive (with a higher level of productivity and higher salaries), it moves into the efficiency-driven stage of development. At that point, competitiveness depends on higher education and training (pillar 5), efficient goods and labor markets (pillars 6 and 7), developed financial markets (pillar 8), the ability to make a good use of existing technologies (pillar 9), and a large domestic or foreign market (pillar 10). And finally, as a country moves into the innovation-driven stage, companies compete by producing new and unique

\footnotetext{
${ }^{2}$ Serbia is in the middle stage of development according to its GDP per capita, whose main driver of competitiveness is the group of pillars "Efficiency enhancers". The measurement of GCI shows that basic requirements participate by $40 \%$, efficiency enhancers by $50 \%$ and innovation and sophistication factors participate by $10 \%$. This means that the values of pillars from the group "'Efficiency enhancers" have the greatest impact on forming the value of Serbia's GCI (Tanasković \& Ristić, 2017, p. 9).
} 
products, using sophisticated production processes (pillar 11) and by innovating (pillar 12). This means that the growth of productivity and competitiveness for countries in the highest stage of development (innovation-driven stage) is determined by innovation and sophistication factors, as shown in the Figure 1. In knowledge-based economies, the main driver of economic development is productivity growth, which is determined by technological and organizational innovations.

„With the development of global economy, higher education has obtained a new strategic role as a central resource of competitiveness, a measure of capacity for attracting and retaining highly qualified workforce and investments. Knowledge is perceived as goods“" (Kovacevic \& Pavlovic, 2016, pp. 97). In the knowledge economy, education and knowledge, play a key role in creating innovations as the basis for acquiring competitive advantage, at the enterprise level and at the level of national economies. Competitiveness strategy, which is based on innovations, can enable Serbia to gain and sustain competitive advantage through entrepreneurship and innovation of companies by improving technological development, in which reformed scientific and educational systems will play a vital role. In the time of growing technological innovations and strong competitive pressures in the open market, companies, as the key drivers of development, must use technological development for improving quality and other performances of their products and services and for strengthening their cost and technological competitiveness on domestic and foreign markets (Bošnjak, 2005, pp. 131-132).

\section{Figure 1: The Global Competitiveness Index framework}

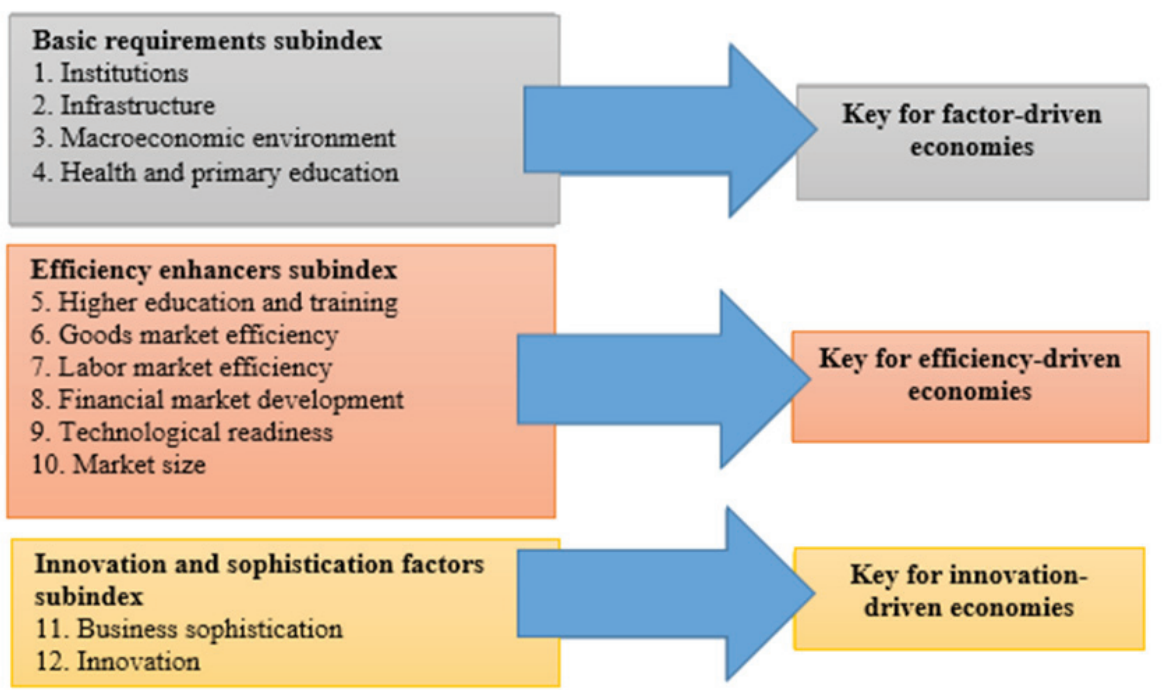

Source: Račić, Ž., Pavlović, N. (2011): The analysis of the Global Competitiveness Index of the Republic of Serbia. Selected papers from the scientific conference ' 'Contemporary trends in European economy-implications for Serbia', Novi Sad, Business School 
'Technological innovations are essential for economic competitiveness. They are the main factor for improving a company's competitiveness, the significance of which is increasing in modern economy, and which is characterized by the concept of knowledgebased development. In innovating countries and countries that are leaders in technological development, in accordance with the demand of competitiveness of real economies, the technology component is assigned a higher weight- 50\%" (Mitrović \& Mitrović, 2015, p. 701). Cortes and Navarro (2011, p. 31) stated that technological innovations have a two-fold effect on the development. On one hand, they directly improve people's skills through their contributions in various areas, such as healthcare and education. On the other hand, technological innovations represent a means for achieving development because of their positive impact on economic growth. Moreover, some authors (Dani, 2007) have pointed out that a long-term ability of a country to produce and compete on the global market is primarily determined by the ability and speed of adopting technological innovations.

Innovations represent a special pillar of the GCI, which is particularly important for the countries in the higher stages of development, which rely on innovations in their development. The results of empirical researches show that $50-60 \%$ of economic growth can be attributed to technological innovations (Milisavljević, 1993, p. 18). Moreover, the position of companies on the international market is primarily determined by the level and intensity of technological development, and then by the differences in price, quality of products and other aspects of business (Ivanović-Đukić \& Lazić, 2014, p. 52). The final pillar of competitiveness focuses on technological innovations. In countries in the highest stage of development, firms need to design and develop cutting-edge products and processes to maintain a competitive edge. This progression requires an environment that is conducive to innovative activity which is supported by both the public and the private sectors. More precisely, it implies sufficient investment in research and development (R\&D), especially by the private sector, the presence of high-quality scientific research institutions that can generate the basic knowledge needed to build the new technologies, extensive collaboration in research and technological development between universities and industry, and the protection of intellectual property.

A society based on knowledge influences business environment making it more complex, dynamic and competitive. Moreover, that complexity and dynamics will increase the growth rate. Under these conditions, the success of business depends on: the proper interpretation of the threats and possibilities in the business environment, efficiency in decision making, adoption and application of knowledge and innovations (Huber, 2003, p. 5). The only way to sustain competitive advantage is to achieve continuity in creating new ideas and the application of innovations.

\section{Innovation of Serbia compared to other countries in the region}

Other problems that hinder the development of innovation of companies in Serbia are inadequate business orientation, organizational culture and the consciousness of managers. Namely, a lack of market orientation and the consciousness of managers that the permanent competitive advantage can be achieved by connecting and cooperating with the key stakeholders (consumers, suppliers, intermediaries, competitors, research 
institutions, universities) are critical factors for the improvement of innovation capacities and business performance of companies. Creating and transferring knowledge through various types of business networks can achieve a high level of specific, and very often, specialized competencies needed for increasing innovation capacity (Stanković, Đukić \& Popović, 2014, p. 279). Creating business networks which integrate various types of companies accelerates economic growth and combines knowledge. The motive for forming associations is the access to complementary knowledge (Krstić \& Vukadinović, 2008 , p. 87). The so-called "smart growth" is based on wider application of modern technologies, development of innovations, transfer of knowledge, expanding research capacities, recruiting creative staff and applying their ideas to products and processes, whereby this kind of growth must create conditions for a new growth that implies a higher level of productivity and competitiveness.

From the aspect of innovation, according to the latest data, Serbia is ranked $95^{\text {th }}$ in a list of 137 countries, with the best score in the past 7 years, according to the methodology of the World Economic Forum (Table 1). Compared to its surrounding countries, Serbia holds a more favorable position than Bosnia and Herzegovina, Romania and Croatia, a country which has suffered a serious rankings drop, while over the seven-year period of analysis Serbia has improved its ranking by moving two positions higher, compared to the results from 2011. Moreover, Serbia had the worst ranking in 2015 (taking into account the last seven years) when it was ranked $113^{\text {th }}$ in a list of 140 analyzed countries, while it achieved its best ranking and the highest score in the last analyzed year (2017). Nevertheless, a very unfortunate fact reveals that our country's ranking has always been lower than the average ranking of the neighboring countries, whereby in 2013 and 2015 the unfavorable difference between Serbia and the surrounding countries was at its highest point (35 positions), while in the last analyzed year, that difference was significantly reduced (12 positions). When it comes to the average ranking of the seven-year period of analysis, Serbia has a much lower average ranking compared to the average ranking of its surrounding countries- 27 positions. Serbia is lagging behind its surrounding countries because of the lack of infrastructure for encouraging creativity, the lack of innovation of companies and because it needs a stronger entrepreneurship. Other problems that occur are the mismatch between the education and the demands of competitive economy, as well as the inability of the job market to attract and preserve talented workforce (Balšić, 2016, p. 92).

Table 1: Comparative representation of the Global Competitiveness Index of Serbia and the countries in the region

\begin{tabular}{|c|c|c|c|c|c|c|c|c|c|c|c|c|c|c|c|c|}
\hline Year & \multicolumn{2}{|c|}{ 2011/2012 } & \multicolumn{2}{|c|}{$2012 / 2013$} & \multicolumn{2}{|c|}{$2013 / 2014$} & \multicolumn{2}{|c|}{$2014 / 2015$} & \multicolumn{2}{|c|}{$2015 / 2016$} & \multicolumn{2}{|c|}{$2016 / 2017$} & \multicolumn{2}{|c|}{$2017 / 2018$} & \multirow{2}{*}{\multicolumn{2}{|c|}{$\begin{array}{l}\text { The average } \\
\text { scores and } \\
\text { ranks of the } \\
\text { analyzed } \\
\text { period* }\end{array}$}} \\
\hline $\begin{array}{l}\text { Number of } \\
\text { analyzed } \\
\text { countries }\end{array}$ & \multicolumn{2}{|c|}{142} & \multicolumn{2}{|c|}{144} & \multicolumn{2}{|c|}{148} & \multicolumn{2}{|c|}{144} & \multicolumn{2}{|c|}{140} & \multicolumn{2}{|c|}{138} & \multicolumn{2}{|c|}{137} & & \\
\hline Country & score & rank & score & rank & score & rank & score & rank & score & rank & score & rank & score & rank & score & rank \\
\hline Serbia & 2.9 & 97 & 2.8 & 111 & 2.9 & 112 & 2.9 & 108 & 2.9 & 113 & 3.0 & 108 & 3.1 & 95 & 2.9 & 106 \\
\hline Albania & 2.6 & 123 & 2.6 & 123 & 2.8 & 119 & 2.7 & 120 & 2.8 & 118 & 3.0 & 109 & 3.2 & 87 & 2.8 & 114 \\
\hline $\begin{array}{l}\text { Bosnia and } \\
\text { Herzegovina }\end{array}$ & 2.8 & 104 & 3.1 & 80 & 3.3 & 63 & - & - & 2.8 & 115 & 2.7 & 125 & 2.7 & 123 & 2.9 & 102 \\
\hline Bulgaria & 2.9 & 93 & 3.0 & 92 & 3.0 & 105 & 2.9 & 105 & 3.1 & 94 & 3.4 & 65 & 3.3 & 68 & 3.1 & 89 \\
\hline
\end{tabular}




\begin{tabular}{|l|c|c|c|c|c|c|c|c|c|c|c|c|c|c|c|c|}
\hline Croatia & 3.1 & 76 & 3.1 & 74 & 3.1 & 79 & 3.1 & 93 & 3.1 & 92 & 3.1 & 103 & 2.9 & 106 & $\mathbf{3 . 1}$ & $\mathbf{8 9}$ \\
\hline Hungary & 3.6 & 34 & 3.6 & 37 & 3.5 & 47 & 3.5 & 50 & 3.4 & 51 & 3.2 & 80 & 3.4 & 62 & $\mathbf{3 . 5}$ & $\mathbf{5 2}$ \\
\hline Macedonia & 2.8 & 105 & 2.8 & 110 & 3.1 & 86 & 3.3 & 68 & 3.4 & 58 & 3.4 & 51 & - & - & $\mathbf{3 . 1}$ & $\mathbf{8 0}$ \\
\hline Montenegro & 3.4 & 50 & 3.3 & 60 & 3.4 & 54 & 3.4 & 58 & 3.3 & 69 & 3.1 & 94 & 3.2 & 91 & $\mathbf{3 . 3}$ & $\mathbf{6 8}$ \\
\hline Romania & 2.9 & 95 & 2.9 & 102 & 3.0 & 97 & 3.3 & 66 & 3.2 & 75 & 3.1 & 93 & 3.1 & 96 & $\mathbf{3 . 1}$ & $\mathbf{8 9}$ \\
\hline Slovenia & 3.6 & 40 & 3.9 & 32 & 3.6 & 40 & 3.6 & 42 & 3.8 & 33 & 3.9 & 33 & 4.0 & 35 & $\mathbf{3 . 8}$ & $\mathbf{3 6}$ \\
\hline $\begin{array}{l}\text { The average } \\
\text { score of } \\
\text { the region } \\
\text { (wi h o u t } \\
\text { Serbia)*** }\end{array}$ & $\mathbf{3 . 1}$ & $\mathbf{8 0}$ & $\mathbf{3 . 1}$ & $\mathbf{7 9}$ & $\mathbf{3 . 2}$ & $\mathbf{7 7}$ & $\mathbf{3 . 2}$ & $\mathbf{7 5}$ & $\mathbf{3 . 2}$ & $\mathbf{7 8}$ & $\mathbf{3 . 2}$ & $\mathbf{8 4}$ & $\mathbf{3 . 2}$ & $\mathbf{8 3}$ & $\mathbf{3 . 2}$ & $\mathbf{7 9}$ \\
\hline
\end{tabular}

Source: $\operatorname{WEF}(2011,2012,2013,2014,2015,2016,2017)$

*The average score of the analyzed period (2011-2017) was obtained

by calculating the arithmetic mean.

** The average score of the region (without Serbia) was obtained

by calculating the arithmetic mean.

According to the latest data, from the aspect of innovation, Slovenia has the best ranking among all countries in the region, while Bosnia and Herzegovina is ranked the lowest. During the whole period of analysis, Slovenia had the best ranking compared to other countries in the region, except in 2011 when Hungary was the highest ranked country among the countries in our region. Montenegro had the greatest ratings drop in the field of innovations (from rank 50 in 2011 to rank 91 in 2017), while Macedonia ${ }^{3}$ achieved the greatest improvement (from rank 105 to rank 51). Slovenia had the highest average ranking during the analyzed period, followed by Hungary and Montenegro, while the lowest average ranking during the seven-year period belonged to Albania (rank 114), followed by Serbia (rank 106) and Bosnia and Herzegovina (rank 104). This statistics shows that Serbia had the worst average ranking in the seven-year period among all its neighboring countries, except from Albania.

Although Serbia is characterized by a low level of government investments in advanced technology that would support innovation and high-tech capacities, in order to reach a higher stage of development it is not enough to just increase total investment in research and development. Serbia is facing various limitations that need to be overcome: inadequate number of researchers, human capital flight, obsolete structure of R\&D sector with the public sector being dominant over the business sector, poor scientific and research cooperation between the academic and business sector, inadequate and unplanned use of the available national resources and the available EU funds (Jakopin, 2013, p. 9). These obstacles are jeopardizing the future development of innovation of our country, which is an important determinant of competitiveness.

\section{The main weaknesses of domestic innovation-the analysis of indicators}

The last pillar of competitiveness within the GCI - innovation, involves the following indicators: 1. capacity for innovation, 2. quality of scientific research

\footnotetext{
${ }^{3}$ Macedonia was not included in the last report of the World Economic Forum, this data refers to the year 2016 .
} 
institutions, 3. companies spending on $\mathrm{R} \& \mathrm{D}$, 4. university-industry collaboration in $\mathrm{R} \& \mathrm{D}, 5$. government procurement of advanced technology products, 6. availability of scientists and engineers and 7. PCT patent applications. By analyzing the scores and the rankings of countries with regard to these indicators, we can determine the main weaknesses and limitations of the national innovation.

Our country has an unfavorable ranking (Table 2) when it comes to innovative capacity (ranked $117^{\text {th }}$ in the list of 137 countries in 2017) and when it comes to companies investing in R\&D (ranked $107^{\text {th }}$ ). Nevertheless, Serbia has a favorable ranking in terms of quality of scientific research institutions (ranked $47^{\text {th }}$ ) and PCT patent application, or the number of patent applications per million population (ranked $50^{\text {th }}$ ).

Capacity for innovation, generally speaking, refers to a country's potential to produce using new knowledge and skills. Business risk is reduced by strengthening capacity for innovation of the economy and companies. In order to increase capacity for innovation, it is important to become part of various kinds of innovation networks, internal or external, i.e. to connect all parts of the organization, as well as to connect with other subjects in order to gain knowledge, which is the key innovation resource. These kinds of networks stimulate innovations, efficient development, transfer of knowledge and technology, globalization of business, new business models and market approaches. Bosnia and Herzegovina and Croatia are our only neighboring countries that have lower rankings than Serbia from the aspect of capacity for innovation (ranked $117^{\text {th }}$ in the list of 137 countries), whereby Croatia's ranking has drastically dropped in the past years (from rank 64 in 2011 to rank 120 in 2017). Moreover, Albania has made a noticeable improvement, from being ranked $119^{\text {th }}$ in the first year of the analysis to being ranked $46^{\text {th }}$ according to the latest data. Although our country has improved its ranking by moving up 13 positions from the last year, this indicator is the main weakness of domestic innovation and a restriction on the improvement of competitiveness. The structure of the capacity for innovation of an economy is determined by the innovation infrastructure of the economy, innovative environment in national industrial clusters and the relationships between the joint innovation infrastructure and specific clusters (Ristić, Vukajlović \& Brazaković, 2016, p. 20).

Table 2: Representation of the Global Competitiveness Index by factors for Serbia (2011-2017)

\begin{tabular}{|c|c|c|c|c|c|c|c|c|c|c|c|c|c|c|}
\hline \multirow{2}{*}{ Year } & \multicolumn{2}{|c|}{ 2011/2012 } & \multicolumn{2}{|c|}{ 2012/2013 } & \multicolumn{2}{|c|}{ 2013/2014 } & \multicolumn{2}{|c|}{ 2014/2015 } & \multicolumn{2}{|c|}{ 2015/2016 } & \multicolumn{2}{|c|}{ 2016/2017 } & \multicolumn{2}{|c|}{ 2017/2018 } \\
\hline & score & rank & score & rank & score & rank & score & rank & score & rank & score & rank & rank & score \\
\hline 1. Capacity for innovation & 2.5 & 110 & 2.5 & 120 & 2.8 & 133 & 3.0 & 130 & 3.1 & 132 & 3.2 & 130 & 3.5 & 117 \\
\hline $\begin{array}{l}\text { 2. Quality of scientific } \\
\text { research institutions }\end{array}$ & 3.8 & 61 & 3.6 & 67 & 3.7 & 66 & 3.7 & 69 & 3.8 & 67 & 4.0 & 60 & 4.2 & 47 \\
\hline $\begin{array}{l}\text { 3. Company spending on } \\
\text { R\&D }\end{array}$ & 2.4 & 130 & 2.3 & 132 & 2.5 & 127 & 2.5 & 125 & 2.4 & 129 & 2.7 & 121 & 2.9 & 107 \\
\hline $\begin{array}{l}\text { 4. University-industry } \\
\text { collaboration in } R \& D\end{array}$ & 3.4 & 81 & 3.2 & 99 & 3.2 & 104 & 3.2 & 95 & 3.2 & 95 & 3.2 & 96 & 3.2 & 95 \\
\hline $\begin{array}{l}\text { 5. Gov't procurement of } \\
\text { advanced tech. products }\end{array}$ & 3.4 & 92 & 3.1 & 115 & 2.8 & 123 & 2.9 & 122 & 2.8 & 110 & 2.8 & 108 & 2.8 & 105 \\
\hline $\begin{array}{l}\text { 6. Availability of scientists and } \\
\text { engineers }\end{array}$ & 3.9 & 83 & 3.9 & 78 & 3.9 & 85 & 3.9 & 82 & 3.8 & 82 & 3.7 & 90 & 3.9 & 68 \\
\hline $\begin{array}{l}\text { 7. PCT patent applications } \\
\text { applications/million pop. }\end{array}$ & 0.4 & 67 & 0.0 & 119 & 2.8 & 53 & 2.3 & 55 & 3.0 & 53 & 3.8 & 50 & 4.1 & 50 \\
\hline
\end{tabular}

Source: $\operatorname{WEF}(2011,2012,2013,2014,2015,2016,2017)$ 
By performing a comparative analysis of Serbia and the countries in the same region, we can conclude that Serbia has a better competitive position in the fields of PCT patent application compared to four countries: Albania, Bosnia and Herzegovina, Montenegro and Romania, whereby Macedonia was not included in the analysis in 2017, but according to the data from the previous year, its ranking was lower than Serbia's ranking with regard to this indicator. In 2012 Serbia had its lowest ranking with regard to this indicator in the seven-year period, which was the second lowest ranking of all the countries in the region (Albania had the lowest ranking then), but Serbia improved its ranking in 2017 when it moved from the $117^{\text {th }}$ position to the $50^{\text {th }}$ position in the list of 137 countries in the world.

From the aspect of availability of scientists and engineers, Serbia has made a significant improvement in the last years and according to the data from 2017, it has the best ranking compared to all other countries in the region, whereby Slovenia is ranked one position lower. This is the only indicator within the twelve pillars of competitiveness, in relation to which Serbia has the best ranking compared to its neighboring countries. Our country has made an improvement when it comes to this indicator by moving 22 positions up the list compared to the year 2017. On the other hand, according to the latest data, Albania has the lowest ranking, followed by Bosnia and Herzegovina.

With regard to the quality of our scientific research institutions, Serbia has also made a significant improvement in the last years and is now ranked $47^{\text {th }}$, which is a remarkable improvement compared to the previous year (ranked $\left.60^{\text {th }}\right)$. In relation to this indicator, Serbia has the best ranking among other countries in the region, except for Slovenia (ranked $29^{\text {th }}$ ) and Hungary (ranked $34^{\text {th }}$ ), while Albania has been characterized by a far poorer quality of scientific research institutions compared to other countries in the region in all years of analysis, according to the GCI report. Hungary had long been a country with the highest quality of scientific research institutions compared to other countries in the region, but in the previous two years Slovenia outscored it.

Table 3: Comparative representation of the Global Competitiveness Index by factors for the countries in the region (2011-2017)

\begin{tabular}{|c|c|c|c|c|c|c|c|c|c|c|}
\hline & \multirow{2}{*}{ Year } & Albania & $\begin{array}{c}\text { Bosnia and } \\
\text { Herzegovina }\end{array}$ & Bulgaria & Croatia & Hungary & Macedonia & Montenegro & Romania & Slovenia \\
\hline & & $\begin{array}{l}\text { score/ } \\
\text { rank }\end{array}$ & score/rank & $\begin{array}{l}\text { score/ } \\
\text { rank }\end{array}$ & $\begin{array}{l}\text { score/ } \\
\text { rank }\end{array}$ & $\begin{array}{l}\text { score/ } \\
\text { rank }\end{array}$ & score/rank & score/rank & $\begin{array}{l}\text { score/ } \\
\text { rank }\end{array}$ & $\begin{array}{l}\text { score/ } \\
\text { rank }\end{array}$ \\
\hline \multirow{7}{*}{$\begin{array}{l}\text { 1. Capacity } \\
\text { for } \\
\text { innovation }\end{array}$} & 2011 & $2.4 / 119$ & $2 . .4 / 124$ & $2.9 / 82$ & $3.1 / 64$ & $3.4 / 41$ & $2.8 / 86$ & $3.2 / 53$ & $2.9 / 78$ & $3.9 / 28$ \\
\hline & 2012 & $2.4 / 128$ & $2.8 / 101$ & $3.2 / 64$ & $3.1 / 72$ & $3.5 / 45$ & $2.8 / 99$ & $3.3 / 53$ & $3.1 / 77$ & $3.9 / 31$ \\
\hline & 2013 & $3.0 / 121$ & $3.1 / 108$ & $3.2 / 103$ & $3.1 / 110$ & $3.2 / 97$ & $3.2 / 94$ & $3.6 / 59$ & $3.4 / 90$ & $3.7 / 54$ \\
\hline & 2014 & $3.2 / 115$ & - & $3.3 / 108$ & $3.1 / 124$ & $3.0 / 127$ & $3.5 / 91$ & $3.6 / 84$ & $3.7 / 68$ & $3.7 / 75$ \\
\hline & 2015 & $3.6 / 103$ & $3.0 / 134$ & $3.8 / 79$ & $3.3 / 122$ & $3.1 / 131$ & $3.7 / 91$ & $3.6 / 100$ & $4.0 / 63$ & $4.4 / 41$ \\
\hline & 2016 & $4.2 / 62$ & $3.1 / 134$ & $4.3 / 59$ & $3.5 / 122$ & $3.8 / 101$ & $4.0 / 82$ & $3.8 / 98$ & $4.0 / 80$ & $4.8 / 31$ \\
\hline & 2017 & $4.4 / 46$ & $3.2 / 132$ & $4.2 / 56$ & $3.4 / 120$ & $3.8 / 96$ & - & $3.9 / 87$ & $3.7 / 109$ & $4.8 / 32$ \\
\hline \multirow{7}{*}{$\begin{array}{l}\text { 2. Quality } \\
\text { of scientific } \\
\text { research } \\
\text { institutions }\end{array}$} & 2011 & $2.2 / 134$ & $3.2 / 98$ & $3.4 / 78$ & $4.1 / 48$ & $5.2 / 20$ & $3.3 / 86$ & $4.1 / 45$ & $3.2 / 91$ & $4.6 / 33$ \\
\hline & 2012 & $2.4 / 132$ & $3.6 / 72$ & $3.5 / 75$ & $4.1 / 48$ & $5.1 / 20$ & $3.2 / 100$ & $3.9 / 54$ & $3.4 / 84$ & $4.8 / 29$ \\
\hline & 2013 & $2.8 / 121$ & $3.9 / 59$ & $3.6 / 68$ & $4.0 / 52$ & $5.2 / 21$ & $3.4 / 86$ & $4.0 / 56$ & $3.7 / 64$ & $4.9 / 29$ \\
\hline & 2014 & $2.6 / 130$ & - & $3.5 / 81$ & $4.0 / 53$ & $5.1 / 23$ & $3.7 / 71$ & $3.9 / 60$ & $4.0 / 55$ & $4.7 / 33$ \\
\hline & 2015 & $2.3 / 137$ & $3.1 / 106$ & $3.7 / 72$ & $4.0 / 52$ & $4.8 / 28$ & $3.9 / 59$ & $3.8 / 65$ & $3.7 / 70$ & $4.8 / 31$ \\
\hline & 2016 & $2.5 / 130$ & $3.2 / 106$ & $3.9 / 64$ & $4.0 / 61$ & $4.5 / 39$ & $4.1 / 53$ & $3.6 / 83$ & $3.8 / 71$ & $4.9 / 28$ \\
\hline & 2017 & $2.8 / 118$ & $3.2 / 106$ & $3.9 / 59$ & $3.8 / 66$ & $4.7 / 34$ & - & $3.7 / 76$ & $4.0 / 57$ & $4.9 / 29$ \\
\hline
\end{tabular}




\begin{tabular}{|c|c|c|c|c|c|c|c|c|c|c|}
\hline \multirow{7}{*}{$\begin{array}{l}\text { 3. Company } \\
\text { spending on } \\
\text { R\&D }\end{array}$} & 2011 & $3.2 / 51$ & $2.8 / 96$ & $2.7 / 98$ & $3.0 / 71$ & $2.9 / 81$ & $2.6 / 109$ & $3.3 / 44$ & $2.9 / 87$ & $3.4 / 39$ \\
\hline & 2012 & $3.0 / 83$ & $2.9 / 90$ & $2.9 / 92$ & $3.0 / 76$ & $2.7 / 103$ & $2.5 / 123$ & $3.2 / 63$ & $2.9 / 87$ & $3.4 / 47$ \\
\hline & 2013 & $3.0 / 82$ & $3.0 / 86$ & $2.8 / 107$ & $3.1 / 65$ & $2.8 / 108$ & $2.9 / 91$ & $3.3 / 54$ & $2.8 / 104$ & $3.2 / 62$ \\
\hline & 2014 & $3.1 / 73$ & - & $2.8 / 100$ & $3.1 / 75$ & $2.9 / 96$ & $3.1 / 67$ & $3.2 / 61$ & $3.1 / 65$ & $3.1 / 72$ \\
\hline & 2015 & $2.9 / 106$ & $2.5 / 124$ & $3.1 / 78$ & $3.1 / 85$ & $2.9 / 97$ & $3.3 / 62$ & $3.1 / 77$ & $2.9 / 94$ & $3.7 / 39$ \\
\hline & 2016 & $2.9 / 104$ & $2.7 / 120$ & $3.5 / 50$ & $3.2 / 79$ & $3.0 / 98$ & $3.4 / 58$ & $3.1 / 82$ & $2.8 / 111$ & $4.1 / 33$ \\
\hline & 2017 & $3.4 / 57$ & $2.6 / 126$ & $3.6 / 44$ & $3.0 / 97$ & $3.1 / 85$ & - & $3.2 / 83$ & $2.8 / 110$ & $4.2 / 33$ \\
\hline \multirow{7}{*}{$\begin{array}{l}4 . \\
\text { University- } \\
\text { industry } \\
\text { collaboration } \\
\text { in R\&D }\end{array}$} & 2011 & $2.1 / 139$ & $3.4 / 84$ & $3.0 / 116$ & $3.5 / 77$ & $4.4 / 33$ & $3.3 / 92$ & $3.7 / 63$ & $3.0 / 115$ & $4.0 / 46$ \\
\hline & 2012 & $2.3 / 138$ & $3.9 / 48$ & $3.0 / 117$ & $3.5 / 80$ & $4.3 / 37$ & $3.2 / 105$ & $3.7 / 60$ & $3.1 / 113$ & $3.9 / 49$ \\
\hline & 2013 & $2.6 / 135$ & $4.3 / 37$ & 3.0/117 & $3.5 / 76$ & $4.3 / 41$ & $3.4 / 81$ & $4.0 / 46$ & $3.3 / 88$ & $3.8 / 56$ \\
\hline & 2014 & $2.3 / 135$ & - & $3.0 / 113$ & $3.4 / 81$ & $4.3 / 35$ & $3.7 / 60$ & $3.9 / 47$ & $3.6 / 71$ & $4.0 / 45$ \\
\hline & 2015 & $2.3 / 134$ & $4.3 / 35$ & $3.0 / 112$ & $3.4 / 81$ & $4.3 / 36$ & $3.7 / 60$ & $3.9 / 46$ & $3.6 / 71$ & $4.0 / 44$ \\
\hline & 2016 & $3.0 / 104$ & $2.8 / 117$ & $3.4 / 74$ & $2.9 / 114$ & $2.9 / 109$ & $3.4 / 70$ & $3.2 / 94$ & $3.3 / 80$ & $3.8 / 42$ \\
\hline & 2017 & $3.4 / 69$ & $2.8 / 111$ & $3.4 / 74$ & $2.7 / 118$ & $3.4 / 68$ & - & $3.2 / 91$ & $3.1 / 97$ & $3.8 / 44$ \\
\hline \multirow{7}{*}{$\begin{array}{l}\text { 5. Gov't } \\
\text { procurement } \\
\text { of advanced } \\
\text { tech. } \\
\text { products }\end{array}$} & 2011 & $3.8 / 58$ & $3.2 / 109$ & $3.5 / 77$ & $2.9 / 122$ & $3.4 / 90$ & $3.1 / 110$ & $4.1 / 33$ & $3.1 / 111$ & $3.4 / 84$ \\
\hline & 2012 & $3.9 / 46$ & $3.3 / 94$ & $3.4 / 81$ & $2.7 / 129$ & $3.1 / 110$ & $3.2 / 102$ & $3.9 / 40$ & $3.1 / 114$ & $3.1 / 106$ \\
\hline & 2013 & $3.7 / 52$ & $3.4 / 89$ & $3.3 / 90$ & $2.6 / 136$ & 3.0/114 & $3.4 / 81$ & $3.9 / 32$ & $3.2 / 99$ & $2.9 / 121$ \\
\hline & 2014 & $3.5 / 70$ & - & $3.2 / 97$ & $2.7 / 129$ & $3.2 / 95$ & $3.6 / 56$ & $3.6 / 57$ & $3.4 / 75$ & 3.0/108 \\
\hline & 2015 & $3.8 / 31$ & $2.4 / 138$ & $3.1 / 86$ & $2.7 / 125$ & $2.9 / 104$ & $3.9 / 22$ & $3.2 / 77$ & $2.9 / 105$ & $2.7 / 120$ \\
\hline & 2016 & $3.9 / 22$ & $2.5 / 126$ & $3.3 / 64$ & $2.5 / 129$ & $2.7 / 114$ & $4.1 / 15$ & $3.1 / 77$ & $2.3 / 134$ & $2.5 / 128$ \\
\hline & 2017 & $3.9 / 25$ & $2.6 / 123$ & $3.3 / 66$ & $2.3 / 134$ & $2.8 / 109$ & - & $3.3 / 74$ & $2.3 / 133$ & $2.6 / 121$ \\
\hline \multirow{7}{*}{$\begin{array}{l}6 . \\
\text { Availability } \\
\text { of scientists } \\
\text { and } \\
\text { engineers }\end{array}$} & 2011 & $3.2 / 126$ & $4.1 / 68$ & $3.7 / 92$ & $3.8 / 88$ & $4.5 / 38$ & $3.4 / 114$ & $4.1 / 70$ & $4.2 / 59$ & $3.8 / 89$ \\
\hline & 2012 & $3.3 / 123$ & $4.4 / 48$ & $3.6 / 98$ & $3.8 / 86$ & $4.4 / 50$ & $3.5 / 106$ & $3.9 / 76$ & $3.8 / 82$ & $3.8 / 84$ \\
\hline & 2013 & $3.5 / 106$ & $4.7 / 27$ & $3.7 / 96$ & $4.0 / 76$ & $4.3 / 60$ & $3.8 / 92$ & $4.0 / 78$ & $3.6 / 99$ & $3.8 / 89$ \\
\hline & 2014 & $3.4 / 110$ & - & $3.6 / 96$ & $3.9 / 79$ & $4.2 / 56$ & $3.9 / 81$ & $4.1 / 69$ & $4.0 / 72$ & $3.9 / 80$ \\
\hline & 2015 & $3.2 / 118$ & $3.1 / 125$ & $3.7 / 90$ & $3.9 / 78$ & $4.2 / 51$ & $3.8 / 86$ & $4.0 / 65$ & $4.1 / 57$ & $4.1 / 62$ \\
\hline & 2016 & $3.1 / 126$ & $3.2 / 119$ & $3.9 / 71$ & $3.7 / 91$ & $3.8 / 83$ & $3.8 / 82$ & $3.8 / 87$ & $4.1 / 60$ & $4.1 / 61$ \\
\hline & 2017 & $3.3 / 113$ & $3.4 / 107$ & $3.6 / 93$ & $3.6 / 95$ & $3.6 / 91$ & - & $3.7 / 85$ & $3.8 / 80$ & $3.9 / 69$ \\
\hline \multirow{7}{*}{$\begin{array}{l}\text { 7. PCT } \\
\text { patent } \\
\text { applications } \\
\text { applications/ } \\
\text { million pop. }\end{array}$} & 2011 & $0.0 / 90$ & $0.0 / 90$ & $7.7 / 30$ & $2.0 / 45$ & $9.1 / 29$ & $0.0 / 90$ & $0.0 / 90$ & $0.8 / 62$ & $12.0 / 26$ \\
\hline & 2012 & $0.0 / 119$ & $2.1 / 50$ & $3.6 / 47$ & $10.0 / 33$ & $22.1 / 27$ & $1.5 / 59$ & $0.0 / 119$ & $1.9 / 56$ & $66.0 / 23$ \\
\hline & 2013 & $0.2 / 91$ & $2.0 / 54$ & $3.7 / 47$ & $10.2 / 33$ & $23.3 / 28$ & $0.7 / 73$ & $3.2 / 49$ & $2.0 / 55$ & $63.1 / 23$ \\
\hline & 2014 & $0.4 / 84$ & - & $5.1 / 48$ & $10.0 / 36$ & $25.0 / 29$ & $0.2 / 91$ & $3.2 / 51$ & $2.2 / 56$ & $63.0 / 23$ \\
\hline & 2015 & $0.2 / 93$ & $2.4 / 55$ & $6.9 / 45$ & $10.3 / 37$ & $24.8 / 26$ & $0.6 / 79$ & $0.8 / 71$ & $2.7 / 54$ & $62.3 / 23$ \\
\hline & 2016 & $0.2 / 90$ & $1.9 / 62$ & $7.0 / 45$ & $9.7 / 41$ & $23.7 / 27$ & $1.5 / 68$ & $3.2 / 54$ & $3.4 / 52$ & $67.8 / 23$ \\
\hline & 2017 & $0.8 / 74$ & $1.7 / 65$ & $7.4 / 47$ & $9.5 / 42$ & $24.7 / 28$ & - & $2.8 / 55$ & $3.9 / 51$ & $71.9 / 23$ \\
\hline
\end{tabular}

Source: WEF (2011, 2012, 2013, 2014, 2015, 2016, 2017)

There is a direct correlation between the quality of national innovation system and the competitiveness of economy according to the methodology of the World Economic Forum (Cvetanović \& Sredojević, 2012, p. 182). The innovation of companies is significantly determined by the collaboration with scientific research institutions. The risk can be reduced or made certain if companies connect and cooperate with scientific research institutions and realize joint projects (Stanković, Đukić, Mladenović \& Popović, 2011, p. 576). In Serbia, only one in four companies develops their own innovations, and only one in eight companies has a long-term cooperation with scientific research institutions. If we observe the relation between the size of companies and the presence of innovations, we can conclude that innovations in smaller companies are present by $29.10 \%$, while in medium companies they are present by $40.32 \%$ (Ivanović-Đukić \& Lazić, 2014, p. 58). Only Bosnia and Herzegovina, Croatia and Romania have a poorer cooperation between industry and universities in R\&D than our country (ranked $95^{\text {th }}$ in the list of 137 countries), which, in addition to capacity for innovation, imposes a severe restriction on improving domestic innovation and competitiveness. In relation 
to this indicator, Slovenia also has the highest ranking of all the countries in our region according to the data from 2017, and it is followed by Hungary and Albania. A very weak connection that exists between the companies and scientific research institutes in Serbia has greatly contributed to the technological backwardness, the inertness of companies and their reluctance to accept new solutions, as well as to the lack of competitiveness of companies and the whole economy (Kokeza, 2015, p. 64).

Serbia has a worse rating in terms of government procurement of advanced technological products (ranked $105^{\text {th }}$ ) only compared to Albania (ranked $25^{\text {th }}$ ), Bulgaria (ranked $66^{\text {th }}$ ) and Montenegro (ranked $74^{\text {th }}$ ), according to the data from 2017, while governments of other countries in the region allocate lower amounts of resources for these purposes, which implies that private sectors in these countries are much more significant in this area. Slovenia has an unfavorable ranking only in relation to this indicator, of all the indicators within the twelve pillars of competitiveness, and is ranked $122^{\text {nd }}$, while Albania has the best ranking (ranked $25^{\text {th }}$ ) according to the latest report of the World Economic Forum. In domestic economy, it is necessary to change the attitude towards knowledge, science and R\&D and it is also important that innovation gains more importance both within the activities of companies and the country as a whole, since without the support from the government there will be no significant achievements in this area. This is the only way to treat resource allocations for R\&D not as expenditure, but as a highly profitable investment in the future (Kokeza \& Urošević, 2012).

In addition to capacity for innovation, as one of the indicators within the twelve pillars of competitiveness, in relation to which Serbia has the worst rating, another poor rating is related to the indicator- companies spending on $\mathrm{R} \& \mathrm{D}$ (ranked $107^{\text {th }}$ in the list of 137 countries). Although our country has significantly improved its rating in relation to this indicator, from being ranked $130^{\text {th }}$ in 2011 to being ranked $107^{\text {th }}$ in 2017, only Bosnia and Herzegovina (ranked $126^{\text {th }}$ ) and Romania (ranked $110^{\text {th }}$ ) have lower ratings compared to other countries in the region, according to the latest data. By far the best ranked country is Slovenia, when it comes to companies spending on $\mathrm{R} \& \mathrm{D}$, followed by Bulgaria. Macedonia and Bulgaria are countries that have made the greatest improvement in the report of the World Economic Forum when it comes to this indicator, compared to the year 2011, while Montenegro has suffered a serious rankings drop, compared to the countries in the region. Tassey (2017, p. 85 ) pointed out that $R \& D$ intensity, i.e. the expenditure on $R \& D$ as a proportion of GDP, is the main indicator of the future potential economic growth, because it represents a part of economy's output invested in technology in order to increase future productivity.

According to one analysis performed by the OECD in 2004, it is estimated that increasing expenditure on $\mathrm{R} \& \mathrm{D}$ in the business sector by $1 \%$ increases productivity by $0.13 \%$, while increasing these investments in the public sector increases productivity by $0.17 \%$. According to another research, increasing R\&D expenditure by $1 \%$ in the business sector (as a \% of GDP) increases the exports of medium and high-technology products by $9 \%$ (as a percentage of total exports) in the same year. Moreover, increasing expenditure in the public sector increases the exports of these products by $8 \%$ in the next two years (Ciocanel \& Pavelescu, 2015, p. 730). When allocating resources for R\&D, it is important to remember that the main goal is to develop innovations. On the other hand, sustainable economic development, the growth of standard of living, better and efficient customer satisfaction and the overall improvement of competitiveness can be achieved only by developing innovations (Sredojević, 2016, p. 161). 


\section{Conclusion}

In the era of globalization, there is a growing interest in new ways for sustaining and improving competitiveness both at macro and micro-level, i.e. at the level of companies and at the level of national economy. There are new demands, imposed by the world market, on which only those who are improving efficiency, productivity and competitiveness are protected. On the global market, the key requirements for strengthening competitiveness of companies, as well as national economy, are new processes, products, methods and procedures, i.e. various kinds of innovations. Under these conditions, the key success factors of modern economies are quality workforce and capacity for innovation.

By analyzing innovation indicators for Serbia and the countries in the region, we have concluded that the main weaknesses of domestic competitiveness stem from the capacity for innovation, insufficient spending of companies on $R \& D$, insufficient government resource allocation for the procurement of advanced technological products and inadequate collaboration of industry and universities. In order to overcome these restrictions imposed on domestic innovation, it is crucial to respond to the demands of economy in order to make a stronger cooperation with universities. It is also essential that the government increases the procurement of advanced technological products and that the private sector gets more encouraged, especially through a more efficient protection of intellectual property. It is also very important to enable domestic innovators to make a profit from their work and thereby achieve competitive advantage, through the protection of intellectual property. The companies play an important role in this by abandoning traditional, hierarchical organizational structures, thus improving their flexibility and strengthening communication. This encourages the creation of new ideas, which is a precondition for innovation at micro and macro-level. Launching innovative activities must begin at micro level, with the support from government.

By performing comparative analysis, we have come to the conclusion that Slovenia is the only country of all the countries in our region which has an exceptional ranking with regard to innovation, since it constantly maintains high scores on all the indicators of the twelfth pillar of the Global Competitiveness Index. On the other hand, Albania is distinguished by the worst ranking, while Serbia has the second least favorable ranking, right after Albania, with regard to innovation. The position of Serbia can be explained by economy's limited innovation capacity, which is primarily determined by the quality of students, researchers, workers and managers. One efficient way for overcoming this limitation is networking, or encouraging innovation networking that enables the transfer of knowledge and technologies and the development of new products and methods, which is highly beneficial for all the parties involved.

In order to encourage innovation, it is necessary to increase spending on $\mathrm{R} \& \mathrm{D}$ and new technologies, both by the government and the private sector, to stimulate private sector investment, to group research facilities into larger scientific centers that would be able to implement strategic projects, to support scientific talents and experts, to strengthen the link between science and industry through tax and other incentives, to subsidize the procurement of equipment for technological development and patenting and to improve efficiency of the protection of intellectual property. 


\section{References}

Balšić, S. (2016). Konkurentnost privrede Republike Srbije. Downloaded on 10.10.2017, from: http://scindeks-clanci.ceon.rs/data/pdf/1452-4457/2016/145244571601081B.pdf

Bošnjak, M. (2005). Konkurentnost i razvoj kao poluge evropske perspektive Srbije. Ekonomski anali, 166, 129-148.

Ciocanel, A. B. \& Pavelescu, F. M. (2015). Innovation and competitiveness in European context. Procedia Economics and Finance 32, 728-737.

Cortes, E. A. \& Navarro, J. A. (2011). Do ICT Influence Economic Growth and Human Development in European Union Countries? International Advance in Economic Research, 17, 28-44.

Cvetanović, S. \& Sredojević, D. (2012). Koncept nacionalnog inovacionog sistema i konkurentnost privrede. Ekonomske teme, 2, 167-185.

Dani, R. (2007). One Economics, Many Recipes: Globalization, Institutions and Economic Growth. Princeton University Press.

Despotović, D. (2016). Komparativna analiza konkurentnosti privrede Republike Srbije i zemalja okruženja u periodu od 2009. do 2014. godine, u: Unapređenje konkurentnosti privrede Republike Srbije, 81-94. Kragujevac: Ekonomski fakultet.

Huber, G. P. (2003). The Necessary Nature of Future Firms: Attributes of Survivors in a Changing World, Thousand Oaks, Calif.: Sage Publications.

Huggins, R. \& Izushi, H. (2007). Competing for Knowledge: Creating, Connecting and Growing. London: Routlegde.

Ivanović-Đukić, M. \& Lazić, M. (2014). Podsticanje inovativnosti malih i srednjih preduzeća u Srbiji u funkciji unapređenja konkurentnosti u postkriznom periodu. Ekonomske teme, 52(1), 49-62.

Jakopin, E. (2013). Institucionalne performanse konkurentnosti privrede Republike Srbije, u: Institucionalne promene kao determinanta privrednog razvoja Srbije, 3-23. Kragujevac: Ekonomski fakultet.

Kokeza, G \& Urošević, S. (2012). Uloga inovativnosti u razvoju malih i srednjih preduzeća. Ekonomski vidici, 17 (1), 37-48.

Kokeza, G. (2015). Inovacije menadžmenta u funkciji unapređenja privrednog razvoja, $\mathrm{u}$ : Inovativna rešenja operacionog menadžmenta za revitalizaciju privrede Srbije, 59-66. Beograd: Fakultet organizacionih nauka.

Krstić, B. \& Vukadinović, D. (2008). Upravljanje znanjem kao izvor održive konkurentnosti preduzeća. Ekonomske teme, 3, 85-98.

Milisavljević, M. (1993). Inovacije i tehnološka strategija preduzeća. Beograd: Ekonomski fakultet.

Mitrović, V. \& Mitrović, I. (2015). Uloga ljudskog kapitala u povećanju konkurentnosti privrede Srbije. International Scientific Conference of IT and Business-Related Research, 699-705. Kosovska Mitrovica: Ekonomski fakultet. 
Pavlovic, N \& Kovacevic, M. (2016). Globalization and the knowledge society. Ekonomika, 62(4), 95-104.

Perez-Moreno, S., Rodriguez, B. \& Luque, M. (2016). Assessing global competitiveness under multi-criteria perspective. Economic Modelling, 53, 398-408.

Račić, Ž., Pavlović, N. (2011) Analiza globalnog indeksa konkurentnosti Republike Srbije. Zbornik sa naučnog skupa Savremeni trendovi u evropskoj ekonomiji implikacije za Srbiju, Visoka poslovna škola strukovnih studija, Novi Sad.

Ristić, N., Vukajlović, V. \& Brazaković, P. (2016). Inovacije kao pokretački faktor razvoja privrede. Ekonomija: teorija i praksa, 9 (1), 19-34.

Schuller, B. \& Lidbom, M. (2009). Competitiveness of Nations in the Global Economy. Is Europe Internationally Competitive? Economics \& Management, 14, 934-939.

Schumpeter, J. (1934). The theory of economic development. Cambridge, Massachusetts: Harvard University Press.

Sredojević, D. (2016). Inovacioni kapacitet privrede kao ograničavajući faktor unapređenja konkurentnosti zemalja Jugoistočne Evrope. Doktorska disertacija, Ekonomski fakultet, Niš.

Stanković, LJ., Đukić, S. \& Popović, A. (2014). Marketing inovacije kao izvor konkurentske prednosti preduzeća. Marketing, 45(4), 271-281.

Stanković, LJ., Đukić, S., Mladenović, I. \& Popović, A. (2011). Unapređenje poslovne konkurentnosti preduzeća zasnovano na inovacijama. Ekonomske teme, 4, 559-580.

Tanasković, S. \& Ristić, B. (2017). Konkurentska pozicija Srbije u 2017. godini prema Izveštaju Svetskog ekonomskog foruma. Downloaded on 07.10.2017, from: https:// www.fren.org.rs/sites/default/files/articles/attachments/KONKURENTNOST\%20 SRBIJE\%20ZA\%202017\%20\%20GODINU-final.pdf

Tassey, G. (2017). A Technology-Based Growth Policy. Issues in Science and Technology, Winter, 80-89.

World Economic Forum (2011). The Global Competitiveness Report 2011-2012. World Economic Forum, Geneva.

World Economic Forum (2012). The Global Competitiveness Report 2012-2013. World Economic Forum, Geneva.

World Economic Forum (2013). The Global Competitiveness Report 2013-2014. World Economic Forum, Geneva.

World Economic Forum (2014). The Global Competitiveness Report 2014-2015. World Economic Forum, Geneva.

World Economic Forum (2015). The Global Competitiveness Report 2015-2016. World Economic Forum, Geneva.

World Economic Forum (2016). The Global Competitiveness Report 2016-2017. World Economic Forum, Geneva.

World Economic Forum (2017). The Global Competitiveness Report 2017-2018. World Economic Forum, Geneva. 